DOI:

\title{
DESIGN OF SUSTAINABLE INDUSTRIAL WATER NETWORKS: 1. GENESIS OF THE SYSTEMATIC METHODS
}

\author{
Arcady Shakhnovsky, Oleksandr Kvitka \\ National Technical University of Ukraine, "Igor Sikorsky Kyiv Polytechnic Institute", \\ Kyiv, Ukraine, e-mail: kxtp@kpi.ua
}

\begin{tabular}{|l|}
\hline Article history: \\
Received 4 January 2018 \\
Accepted 1 April 2019 \\
Print 24 June 2019 \\
\hline
\end{tabular}

The first part of the work is devoted to the review of the history of development and analysis of modern methods of project decision support in the sustainable design of industrial water networks: water usage networks, water treatment networks. Modern methods of computer-aided design of chemical-engineering systems were classified. The industrial water economy system as an integral part of the chemical-engineering system and as an object of design was considered. The modern conceptual and superstructure methods of designing water networks were described.

Keywords: design of chemical-engineering systems, water economy, water usage, water treatment, mathematical programming, pinch analysis, optimization.

\section{Introduction}

Industrial plants design practice in chemical engineering and other settings provides for synthesis of efficient (e.g., cost-beneficial) chemical-engineering system (CES). Designed technology is meant to ensure maximum output, minimum environmental damage, low resources consumption (including nonrenewable natural resources), low waste production, proper working environment, etc. A number of publications (El-Halwagi (1997), Klemeš at al. (2014), Seider at al. (2004), Smith (1999), etc.), including monographs, are devoted to computerized methods and techniques that provide such design.

The so-called "process integration" (PI) is the basic paradigm intended to ensure the proper level of energy and resource efficiency of project facility. Process integration involves consideration of the projected CES as a whole, with a comprehensive consideration of processes and devices, mass and energy flows of the system in their interaction. Thus, PI is opposed to the independent optimal design of CES constituents (also note that synthesis of optimal CES by independent design of CES subsystems requires follow-up merging of individual design solutions at the final stage of synthesis). Process integration allows for the use of "internal reserves" of technology (for example, heating the reagents using the excess heat of reaction products (Smith, 1999). Therefore, being applied systematically, PI demonstrates high effectiveness primarily in design problems with heat recovery (Linhoff \& Hindmarsh (1983), Jeżowski (1995), Smith at al. (2000), etc.).

There is also a growing tendency to involve computer models in the design process. For example, the design procedure by Edgar, 2000 involves the use of computational fluid dynamics calculators for the design and operation (mainly, control) of the process industries.

The development of the design tools for synthesis of CES, along with the development of mathematical modeling and the rapid growth of computer hardware power, offered to scientists and designers scope for creating advanced automatic design software. The new generation of CAD (computer-aided design) software is aimed at providing automatic generation of the whole complex of project documentation following design requirements.

Due to the spreading of the concept of sustainable development, the priorities of design (as well as retrofit design) of industrial facilities had been somewhat shifted. "Designing CES on the principles of sustainable development", or "sustainable design" should now be interpreted as a system of "project activities that lead to economic growth, environmental protection and social progress for the current generation, without compromising the potential of future generations" (El-Halwagi, 2017). 
Thus, the model-based integrated approach to sustainable design of CES components described above is quite promising.

Unfortunately, the complex nature of chemical-engineering system as the subject of design (and, consequently, the complexity of the methodological and mathematical apparatus supporting the design process of CES) is not conducive to integration. Sustainable design techniques that are technologically perfect and cost-effective are still not implemented for CES as a whole. Typically, such design techniques apply only to individual CES subsystems. Manousiouthakis \& Allen (1995) offered six levels of horizontal decomposition of CES. These levels of decomposition are the directions of synthesis of the basic subsystems of CES on the principles of PI. The above-mentioned publication of Manousiouthakis \& Allen (1995), in particular, highlights the synthesis of "reactor system", "separation system", "heat exchange system", "mass exchange system" as parts of the CES.

There is no doubt that the most advanced direction in the synthesis of CES subsystems is the heat exchanger networks (HEN) synthesis, which as long ago as 2002 had already been described in more than 460 publications (Furman K. \& Sahinidis, 2002).

While further expanding the scope of the PI principles to synthesize other subsystems of the CES, researchers (in one way or another) use ideas developed for heat exchange subsystems. The next stage of such an extension was envisaging of waste treatment processes and beneficial using "wastes" as well as by-products. By analogy with the "heat exchange process integration", the problem of integrating mass-exchange processes (e.g., adsorption, extraction, absorption, etc.) appears in the literature as "mass exchangers networks (MEN) synthesis" (see Dunn \& El-Halwagi (2003), El-Halwagi \& Manousiouthakis (1990), El-Halwagi (1997), Hamad \& El-Halwagi (1998), etc.).

Cabezas at al. (1997) as well as Young \& Cabezas (1999) were among the first that formulated the MEN synthesis problem in the context of estimating the "sustainability" of the project. They proposed the so-called "Waste reduction (WAR) algorithm". The remarkable thing is that implementation of concept "sustainable development as a criterion for the functioning of CES" is still a work in progress - see, for example, (Petrescu \& Cormos (2015), Sepiacci at al. (2017), etc.).

The purpose of this paper is to study the development trends of sustainable optimal design procedures of industrial water economy as one of the subsystems of chemical-engineering system.

\section{Industrial water economy}

Industrial water economy subsystem is a set that must meet a number of requirements, which are as follows (Komissarov at al. (2002), Naiman (2004)):

- to provide water demand for all components of a set; the water should be of adequate quality and in the proper quantity;

-to meet the environmental requirements for water discharge;

-to contain properly operating constituents.

The cycle of water use (water economy network (WEN), water life cycle) of the process industries (Statyukha at al., 2003) can be represented by the scheme shown in Fig. 1. As one can see, it consists of:

-water supply unit;

-water use unit;

- water disposal unit.

Water supply unit is a set of natural sources and intake stations, as well as water conditioning, water storage, water delivery systems. Process water is widely used in mass transfer operations, in cyclone separation and filtration, in steam supply systems, etc. Also, water applied for numerous supporting processes (such as equipment washing and so on).

The next stage of the life cycle of water (consumption for various needs) according to the tradition established by Takama at al. (1980), Wang \& Smith (1994a), Wang \& Smith (1995), etc. is called "water usage network".

Thus, water usage network (WUN) is intended to mean the system of interconnected processes that use water for different purposes (for technological needs, for cooling, for energy and auxiliary needs). 
Generically, the process of water use is accompanied by water contamination. As a rule, water contamination is considered in the broadest sense. This could be either introducing into water some pollutants or changing some other conditions that impede further use of water (e.g., changing water temperature, changing water acidity, etc.) - please refer to Ghazouani at al. (2017), Wang \& Smith (1994a), etc.

In the context of PI, the use of resource conservation options (reduction of fresh water consumption) is achieved by directing "partially contaminated" water from the output of one technological unit to the input of another (with the possibility of dilution with fresh water). When the maximum potential for direct reuse is exhausted, the "partially contaminated water" stream may be sent to regeneration (partial treatment) for further reuse (Wang \& Smith, 1994a).

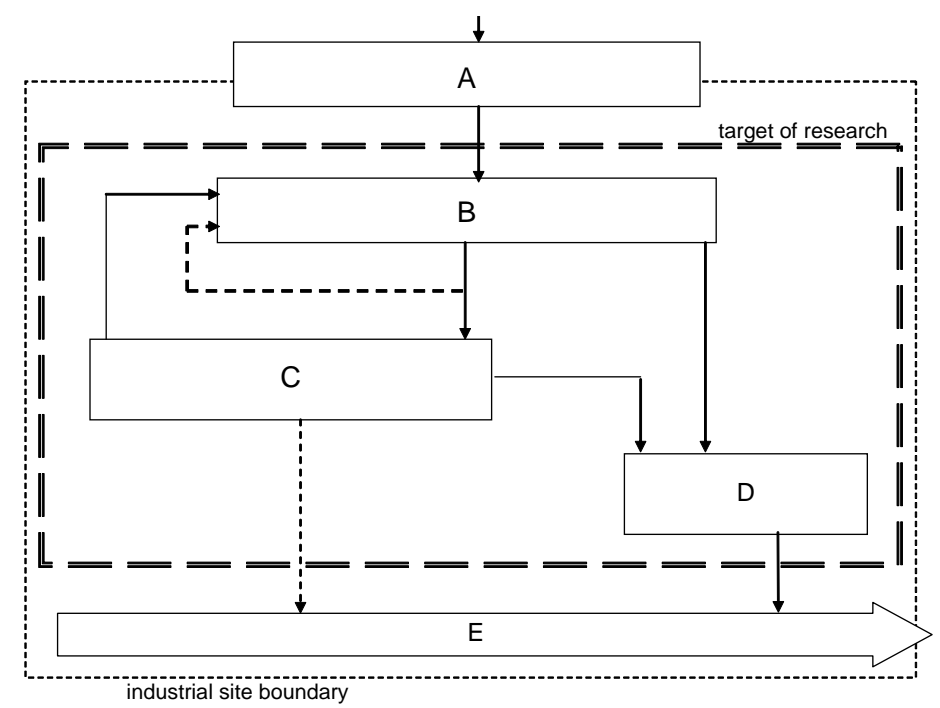

Figure 1 - Life cycle of process water: A - water treatment, water supply; B - water use; C partial treatment (regeneration) for reuse; D - effluent treatment; E - water discharge.

Nowadays the theory of wastewater drain and treatment networks design is in progress. There is an extensive literature on the methods of treatment processes intensification and efficient synthesis of treatment networks. The modern paradigm of creating industrial networks is to reduce waste generation "in heart" of the technological process. In particular, one could notice a tendency to switch from traditional "end-of-pipe" treatment to decentralized treatment (inclusive of the restructuring of existing networks towards decentralization of treatment process), which is more economically justifiable (see Li at al. (2016), Liu at al. (2013), Petrides at al. (1998), Soo at al. (2013), Wang \& Smith (1994b), etc.).

At the same time, in most of the articles the possibility of "indirect" cost saving by reducing the amount of wastewater entering the treatment process is neglected. An analysis of the interconnection of processes at individual stages of the water life cycle is presented by Kutepov at al. (2002). The authors' conclusions can be summarized as follows:

1. Increasing the process water reuse ratio leads to the formation of more concentrated sewage.

2. Wastewater treatment operation costs are determined not only by the qualitative composition of wastes, but also by the amount of wastewater and concentration of contaminants.

3. Mixing of different water streams, results both in the number of contaminants and their dispersion (dilution) in water. This leads to the increase of the value of the system's total entropy. The stability of such a system increases. Therefore, more energy is needed for treating water. Using the concept of exergy (as a quantitative thermodynamic characteristic of degradation (dilution) of aqueous technological streams (sewage)), Kutepov at al., 2002 prove that the efficiency of the wastewater treatment process is in direct ratio to the initial concentrations of contaminant in the wastes. 
4. Since the efficiency of water treatment is directly proportional to the contaminants concentration, it may be concluded that the structural optimization of WUN leads to the intensification of wastewater treatment processes.

The above findings are supported by practical results. Thus, Zhelev \& Bhaw (2000) studied system that included activated sludge plant as well as surrounding production sites (which were consumers of water and the generators of liquid emissions).

The structure of WEN of the mentioned water users was optimized in order to maximize the full use of process water. The authors consider various options for wastewater treatment both before and after WEN optimization. Water treatment costs after optimization have notably decreased. The optimized treatment network was found to be 30 per cent more efficient.

The peculiarities of Ukrainian practice are as follows. As a rule, the design of an optimal WEN is not formulated as an independent task. This problem is formulated as concomitant when designing or upgrading a given enterprise. As a result, aimed to reduce fresh water consumption tend to come in the form of highly specialized, sector-specific recommendations. Additionally, technical solutions, as a rule, are rather subjective and mostly based on one's engineering experience, since the principle of choosing some form of water saving is difficult to formalize. Without denying the importance of such kind of engineering solutions, it should be noted, however, that an empirical approach does not guarantee the optimal result. Consequently, there is a need for a systematic procedure for the sustainable design of the water networks.

When formulating the objective of WEN design, several assumptions have to be made (Mann \& Liu (1999), Shakhnovsky at al. (2004a)). In particular, it is expected that WENs were already subjected to both "administrative" and "parametric" optimization (i.e., all the processes within the WEN can be considered optimal in terms of water consumption). "Administrative" optimization includes regular WEN balance accounting and reporting, rewarding individual staff members for maintaining the water conservation regime, eliminating unplanned water leaks, etc. "Parametric" optimization (changes in technology) is replacement of water consuming devices with alternative ones (e.g., replacement of water cooling with air cooling).

Before turning specifically to analyze the available WEN design procedures, WEN design objective should be formulated in more general terms.

The general design procedure for WEN (Jeżowska at al. (2007), Klemeš at al. (2014), Tainsh \& Rudman (1999)) includes the following three steps:

Step 1. Preparation of input data.

The following sets should be included into optimal WEN design data base:

- a set of WEN design conditions (grassroot design, retrofit design, etc.);

- a set of WEN operating conditions (either periodic or continuous WEN operating mode, etc.);

- a set of external fresh water sources (for example, less contaminated waste water from associated industries can be used);

- a set of characteristics of fresh water sources;

- a set of WEN constituents;

- a set of nominal water flowrates for WEN constituents (in the case of WEN retrofit design, the value water flowrate for water users is predetermined, as a rule; otherwise, these values are given by an acceptable range);

- the set of classes (groups) of contaminants to be eliminated from WEN constituents;

- the set of initial concentrations of contaminants (in the water at input of the processes) and the concentrations of contaminants in water at the output of the processes (subject to the given characteristics of mass transfer);

- the set of water decontamination factors for water treatment processes;

- the set of additional characteristics of the WEN constituents (in particular, the need for a fixed mass flow, a given degree of danger, etc.).

As mentioned above, from the point of view of the processes integration, not only impurity build-up, but also any change in water that prevents its further use (including temperature changes) can be considered as contamination. For the universality of the procedure, it is assumed that the measure of all possible contaminations is concentration. 
Ideal mixing model as well as plug-flow model may act as major units of aggregated mathematical descriptions of water quality transformation process. In the WEN design practice the simplified model of counterflow mass-transfer apparatus is accepted to use as general model of water use and water treatment processes (fig. 2). In particular, for the theoretical substantiation of the allowability of such a significant simplification (taking into account spatial sampling, stationariness assumption, etc.) one can refer to Shakhnovsky at al., 2008.

Since water from the output of one process is proposed to be used in other processes of WEN, it is necessary to have information about the maximum possible concentration (limiting concentration) of each of the contaminants in the water at the input of each of the processes.

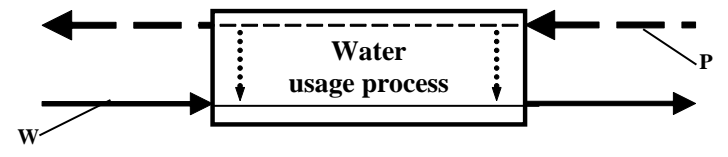

a)

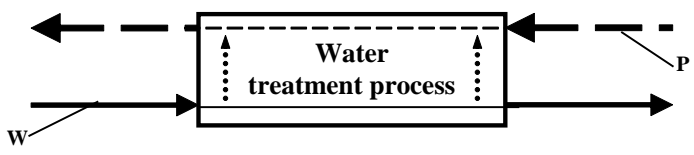

b)

Figure 2 - Representation of the process as part WEN: a) - water use; b) - water treatment; $\mathrm{P}$ is «process technology stream»; $\mathrm{W}$ is water stream.

It is often possible to group contaminants with similar properties. For example, insoluble contaminants (which are inert in relation to CES constituents) can be clustered into "suspended solids" group. In some cases, such clustering makes it possible to reduce the multi-contaminant problem to the case of one contaminant.

Step 2. The procedure for determining the optimal WEN structure.

The sequence of actions in this step may differ significantly depending on the method of synthesis used (see below).

Results of the design procedure should include:

- utilization rates of fresh water sources that are external relative to WEN;

- fresh water flowrate for water users that are parts of the WEN;

- recycle and recharge rates;

- specifications of water treatment equipment.

Step 3. The preparation for the optimal network implementation includes sensitivity analysis of the optimal WEN, feasibility plan and WEN analysis in terms of sustainable development.

\section{Methods of sustainable synthesis of industrial water economy subsystem}

In order to automate the design process, the following features must be present in the design procedure:

a) preventing subjectivity when making design decisions (that are typical of "manual" design);

b) high degree of formalism (this makes it possible to create automated design system);

c) minimization of computing resources required (this is still important for industrial scale problems, despite the rapid development of computer technologies);

d) guarantee for achieving of optimum results;

e) adequacy of the models of CES constituents, etc.

Note that the above mentioned often contradict each other and are typical for some "ideal" design procedure. It is precisely due to this contradiction that there exist many design procedures, a detailed review of which will be presented in the following publications.

Summarizing the recent literature data, one can distinguish two main classes of sustainable design procedures of CES subsystems:

1. Hierarchical methods (also called insight-based, sequential, conceptual methods).

2. Simultaneous methods (otherwise known as superstructural, combinatorial, mathematical optimization-based methods).

The hierarchical method consists in "vertical decomposing". In other words, this method involves splitting complex problems into subproblems. Next, these subproblems are consistently solved in order of their importance. This envisages the use of designers' experience, formulated in the form of some rules (heuristics). 
One of the common ways of presenting design subproblems is the so-called «onion diagram» (Douglas (1988), Jeżowski (1995), Linnhoff at al. (1994), Smith (1999))- see Fig. 3

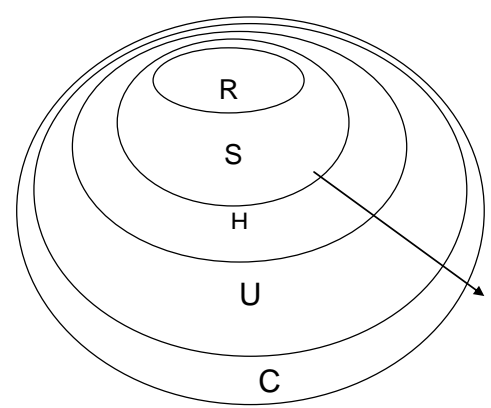

Figure 3 - «Onion diagram» of CES design hierarchy: $\mathrm{R}$ - reactions system; $\mathrm{S}$ - separation system and recycles; $\mathrm{H}$ - heat-exchange system; $\mathrm{U}$ - utility system; $\mathrm{C}$ - control system.

As can be seen from Fig. 3, the hierarchical principle suggests that CES is regarded as a multilayer system. The most important layer is the chemical transformation, so the design process begins with the reactor (or reactors). Since the result of the reactor's operation is a mixture of desired reaction products, reaction by-products and unreacted substances, the next layer is the design of a separation and recycling system.

The CES, containing reactors, flow splitters and process recycles usually needs to change the temperature of some flows (for example, it may be necessary either to heat the substances before feeding to the reactor, or to cool the reaction mixture before separation). Therefore, the next step is the design of heat exchangers networks based on the principles of heat integration. Not all heating (or cooling) needs can be met by heat integrating, so the next step is to calculate the required amount of external heating or cooling flows (heating and cooling utilities).

As can be seen, the hierarchical design approach implies moving sequentially from internal to external layers of design hierarchy. At each stage, special methods of decision-making should be applied, which are characteristic for this stage. As output data, the results obtained from already designed "layers" should be used.

This approach is quite evident and widespread in design practice, but it has obvious drawbacks:

1. The resulting CES is not known in advance. It is also not known whether the resulting network is optimal. In particular, there are several possible options for solving at each of the stages. Therefore, it is impossible to predict whether the chosen solution will give the optimal scheme as a whole.

2. "Interlayer" integration of processes becomes more difficult. Guided by the hierarchical principle, one can't change the structure of the previous stages of the project.

"Simultaneous" methods as an alternative to hierarchical design methods involve building a certain generalized technological network (also called the CES superstructure), which includes all possible options for constructing a CES. That is, the CES superstructure must include all possible (alternative) processes as well as all possible connections between processes. On the basis of the superstructure, a mathematical optimization problem is formulated. Then the optimization problem is solved. After solving the optimization problem, the results are interpreted in the desired optimal CES.

The optimization problem for the CES structure synthesis contains design variables and design equations. Project equations will include a goal function (for example, economic criteria), mathematical models of CES constituents and constraints (as a rule, constraints are made on the basis of material balances).

Notice that "simultaneous" approach is also called "method of structural parameters" by Ukrainian authors (Ostrovsky \& Berezhinsky, 1984). 
The advantage of such an approach is good formalization and therefore the possibility of computer-aided multivariate analysis. Among the disadvantages of the "simultaneous" design approach are the following:

1. An optimal solution will not be obtained if it was not included in the superstructure.

2. The superstructure and optimization problem solved in this method is usually complicated. For example (Jeżowski, 1995), the design superstructure of a mass-exchange network - a system of distillation columns for the separation of a ten-component mixture contains 4862 possible options (unless special heuristic simplification rules were applied). In the case of the complication of the superstructure, the dimension of the mathematical optimization problem show increasing trends. For example (Shakhnovsky at al., 2004b), Figure 4 shows the optimization problem dimension variation with the number of water users and the number of external water sources.

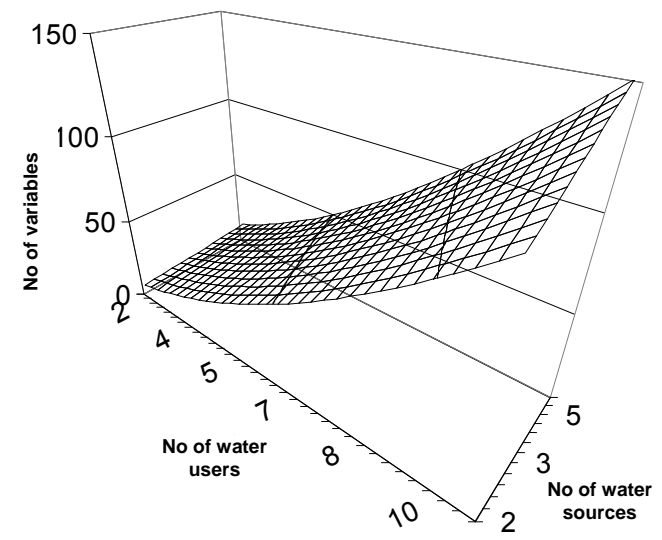

Figure 4 - Growth of the optimization problem dimension depending on the number of water users and the number of external water sources (Shakhnovsky at al., 2004b)

The general case of optimization problem is characterized by multi-extremity. Therefore, in the synthesis of CES, one can also expect computational difficulties associated with the optimization process termination in local extrema, which results in a non-optimal CES structure (Shakhnovsky at al., 2004b).

3. Applying the "simultaneous" approach to designing, it is difficult to take into account some of the project features (for example, safety requirements).

As to the WEN, several publications have identified two groups of design approaches: heuristic ("intuitive") and mathematical programming approaches (please refer to Bagajewicz (2000), Jeżowski (2010), Kutepov at al. (2002), Mann \& Liu (1999), Tainsh \& Rudman (1999), etc.). Such a classification is the most common. But it is not entirely correct, since, as will be shown in subsequent publications; there are reports of attempted mathematical formulation of conceptual design methods.

Poplewski (2015) proposed a functional classification, according to which the following four grades can be differentiated: a) approaches focused on optimizing of fresh water use only; b) approaches that provide both optimal water use and optimal water treatment; c) approaches that take into account the optimal heat transfer in WUN; e) other approaches, including procedures of batchoperated WUN optimization.

Clearly, such a breakdown is based on the well-known decomposition of CES design problems, and quite accurately reflects the current trends in the design of optimal WEN, although it seemed somewhat artificial.

It should be noted that more promising in the sense of computerized design are "simultaneous" methods, which made them more common in modern design practice.

\section{Conclusions}

1. The presented article investigates conditions for the emergence of industrial water economy subsystem synthesis methods based on principles of sustainable development. 
2. The classification of the above-mentioned procedures is made. The competition between insight-based hierarchical and superstructural paradigms in practice of synthesis of sustainable water economy subsystem was shown.

3. Future publications will include studies of modern conceptual and superstructure methods of industrial water economy subsystem design based on presented classification.

\title{
Acknowledgments
}

This paper is dedicated to the memory of Prof. Jacek Jeżowski (Rzeszów University of Technology) and Prof. Gennady Statyukha (National Technical University of Ukraine, "Kyiv Polytechnic Institute").

The paper presented is part of an ongoing research project "Development of sustainable industrial water networks" (state registration No 0117U005297).

\section{ПРОЕКТУВАННЯ СХЕМ ВОДНОГО ГОСПОДАРСТВА ЗА ПРИНЦИПАМИ СТАЛОГО РОЗВИТКУ: 1. ГЕНЕЗА СИСТЕМНИХ МЕТОДІВ.}

\author{
Аркадій Шахновський, Олександр Квітка \\ Національний технічний університет України "Київський політехнічний інститут ім. Ігоря \\ Сікорського", Київ, Україна, e-mail: kxtp@kpi.ua
}

Перша частина публікащії присвячена огляду генези сучасних методів підтримки проектних рішень при проектуванні технологічних схем водного господарства промислового підприємства: схем водоспоживання та водоочищення, за принципами сталого розвитку.

Розглянуто водне господарство промислового підприємство як складову частинухімікотехнологічної системи і як об'єкт проектування.

Проведено класифікацію сучасних методів сталого автоматизованого проектування підсистем водного господарства у складі хіміко-технологічних систем. За результатами аналізу парадигм проектування хіміко-технологічних систем та споріднених технологічних систем (нафтопереробка, металургія, тощо) на сталого розвитку у відповідності до концепиії інтегрування процесів кластеризовано методи сталого проектування підсистем водного господарства промислових підприємств.

Показано, щуо сучасні методи підтримки проектних рімень при проектуванні схем водного господарства можуть бути поділені на два класи: послідовні (ієрархічні, кониептуальні) та «одночасні» (комбінаторні, надструкутурні) методи. Виділено характерні особливості концептуальних та надструктурних методів проектування систем водного господарства.

Ключові слова: проектування хіміко-технологічних систем, водне господарство, водоспоживання, водовідведення, очищення води, математичне програмування, пінч-аналіз, оптимізація.

\section{ПРОЕКТИРОВАНИЕ СХЕМ ВОДНОГО ХОЗЯЙСТВА В СООТВЕТСТВИИ С ПРИНЦИПАМИ УСТОЙЧИВОГО РАЗВИТИЯ: 1. ГЕНЕЗИС СИСТЕМНЫХ МЕТОДОВ.}

\author{
Аркадий Шахновский, Александр Квитка
}

Национальный технический университет Украины "Киевский политехнический институт им. Игоря Сикорского", Киев, Украина, e-mail: kxtp@kpi.ua

Первая часть публикации посвящена обзору истории развития и анализу современных методов поддержки проектных решений при проектировании технологических схем водного хозяйства промышленного предприятия: схем водопотребления и водоочистки, на принципах

Вода і водоочисні технології. Науково-технічні вісті·№1(24) 2019 
устойчивого развития. Классифицировань современные методы автоматизированного проектирования химико-технологических систем. Рассмотрено водное хозяйство промышленного предприятие как составная часть химико-технологической системы и как объект проектирования. Охарактеризованы современные концептуальные $u$ сверхструктурные методы проектирования систем водного хозяйства.

Ключевые слова: проектирование химико-технологических систем, водное хозяйство, водопотребление, водоотведение, очистка воды, математическое программирование, пинчанализ, оптимизация.

\section{References}

Bagajewicz M. A review of recent design procedures for water networks in refineries and process plants. Comp. \& Chem. Engng. 2000. 34, 2093-2113. doi: https://doi.org/10.1016/S0098$\underline{1354(00) 00579-2}$

Cabezas H., Bare J. C., Mallick S. K. Pollution prevention with chemical process simulators: The generalized waste reduction (WAR) algorithm. Comp. \& Chem. Engng. 1997. 21, 305-310. doi: https://doi.org/10.1016/S0098-1354(98)00298-1

Douglas J. M. Conceptual design of chemical processes. (New York: McGraw-Hill, 1988).

Dunn R. F., El-Halwagi M. M. Process Integration Technology Review: Background and Applications in the Chemical Process Industry. J. Chem. Techn. \& Biotechn. 2003. 78, 1011-1021. doi: https://doi.org/10.1002/jctb.738

Edgar T. F. Process information: achieving a unified view. Chem. Engng. Progr. 2000. 96(1), 5157. ResearchGate:

https://www.researchgate.net/publication/285538880_Process_information_Achieving_a_unified_v iew

El-Halwagi M., Manousiouthakis M. Automatic synthesis of mass-exchange networks with singlecomponent targets. Chem. Engng. Sci. 1990. 45(9), 2813-2831. doi: https://doi.org/10.1016/00092509(90)80175-E

El-Halwagi M. M. Pollution prevention through process integration. (San Diego: Academic Press, 1997).

El-Halwagi M. Sustainable Design Through Process Integration: 2nd Edition. (Amsterdam-OxfordCambridge: Elsevier. 2017).

Furman K. C., Sahinidis N. V. A critical review and annotated bibliography for heat exchanger network synthesis in the 20th century. Ind. \& Engng. Chem. Res. 2002. 41, 2335-2370. doi: $10.1021 / \mathrm{ie} 010389 \mathrm{e}$

Ghazouani S., Zoughaib A., Le Bourdiec S. An MILP model for simultaneous mass allocation and heat exchange networks design. Chem. Eng. Sci. 2017. 158, 411-428. doi: https://doi.org/10.1016/j.ces.2016.10.041

Hamad A., El-Halwagi M. Simultaneous Synthesis of Mass Separating Agents and Interception Networks. Chem. Eng. R\&D. 1998. 76(3), 376-388. doi: https://doi.org/10.1205/026387698524802 Jeżowska A., Jeżowski J., Kvitka O., Statyukha G., Shakhnovsky A. Collecting and processing the source data for the industrial water usage networks design. Visnyk Zhytomyrskogo derzhavnogo inzhenerno-tekhnologichnogo universytetu. 2007. 40(1), 213-218. [In Ukrainian]. doi: https://doi.org/10.26642/tn-2007-1(40)-213-218

Jeżowski J. Design of heat recovery subsystems under certain data conditions. (Rzeszów: OW PRz, 1995). [In Polish].

Jeżowski J. Review of Water Network Design Methods with Literature Annotations. Ind. \& Engng. Chem. Res. 2010. 49, 4475-4516. doi: 10.1021/ie901632w

Klemeš J. J., Varbanov P. S., Wan Alwi S., Manan Z. A. Process Integration and Intensification: Saving Energy, Water and Resources. (Berlin/Boston: Walter de Gruyter GmbH \& Co KG., 2014). Komissarov Yu.A., Gordeev L.S., Nguen N.S. Analysis and synthesis of water supply systems for chemical plants: Study guide for universities. (Moscow: Khimiya, 2002). [In Russian]. 
Kutepov A. M., Meshalkin V.P., Nevskii A.V. Environmental technology: Exergy analysis in the design of water-saving technological systems. Inzhenernaya ekologiya (Engineering ecology). 2002. 1, 50-57. [In Russian]. Istina: https://istina.msu.ru/publications/article/101828628/

Linhoff B., Hindmarsh E. The pinch design method of heat exchanger networks. Chem. Engng. Science. 1983. 38, 745-763. doi: 10.1016/0009-2509(83)80185-7

Linnhoff B., Townsend D. W., Boland D., Hewitt G. F., Thomas B., Guy A. R., Marsland R. H. User Guide on Process Integration. (Rugby, UK: The Institution of Chemical Engineers, 1994).

Li A.-H., Zhang J., Liu Z.-Y. Design of distributed wastewater treatment networks of multiple contaminants with maximum inlet concentration constraints. J. Clean. Product. 2016. 118, 170-178. doi: https://doi.org/10.1016/j.jclepro.2016.01.052

Liu Z.-H., Shi J., Liu Z.-Y. Design of distributed wastewater treatment systems with multiple contaminants. Chem. Eng. J. 2013. 228, 381-391. doi: https://doi.org/10.1016/j.cej.2013.04.112

Mann J. G., Liu Y. A. Industrial water reuse and wastewater minimization. (New York: McGrawHill. 1999).

Manousiouthakis, V., Allen, D. Process Synthesis for Waste Minimization. Foundations of Computer Aided Process Design, AIChE Symposium Series. 1995. 91, 72-86.

Naiman S. M. Some economic aspects of the assessment of surface runoff from the enterprise territory. Ekologya promyshlennogo proizvodstva (Ecology of industrial production). 2004. 8(3), 3944. [In Russian]. Elibrary: https://elibrary.ru/item.asp?id=17049159

Ostrovsky G. M., Berezhinsky T. A. Optimization of chemical technological processes. (Moscow: Khimiya, 1984). [In Russian].

Petrescu L., Cormos C.-C. Waste reduction algorithm applied for environmental impact assessment of coal gasification with carbon capture and storage. J. Clean. Product. 2015. 104, 220-235. doi: https://doi.org/10.1016/j.jclepro.2014.08.064

Petrides D., Cruz R., Calandranis J. Optimization of Wastewater Treatment Facilities Using Process Simulation. Comp. \& Chem. Engng. 1998. 22, 339-346. doi: https://doi.org/10.1016/S00981354(98)00073-8

Poplewski G. A new methodology for the synthesis of an optimum flexible water networks. Process Safety and Environmental Protection. 2015. 95, 172-183. doi: https://doi.org/10.1016/j.psep.2015.03.001

Seider W. D., Seader J.D., Lewin D.R.: Process design principles. (New York: John Waley \& Sons Inc., 2004).

Sepiacci P., Depetri V., Manca D. A systematic approach to the optimal design of chemical plants with waste reduction and market uncertainty. Comp. \& Chem. Engng. 2017. 102, 96-109. doi: https://doi.org/10.1016/j.compchemeng.2016.11.032

Shakhnovsky A. Jeżowski J., Kvitka A., Jeżowska A., Statiukha G. Investigations on optimization of water networks with the use of mathematical programming. Inżynieria chemiczna i procesowa. 2004a. 25(3/3), 200-500. [In Polish]. YADDA: bwmeta1.element.baztech-article-BGPK-1139-4438 Shakhnovsky A., Jeżowski J., Statyukha G., Kvitka O. The optimality problem in the problems of industrial water usage networks synthesis. Res. Bull. of NTUU "KPI". 2004b. 6, 35-41.

Shakhnovsky A., Jeżowski J., Jeżowska A., Statyukha G., Kvitka O. Mathematical description of units of water consumption for enterprise water usage networks. Visnyk Odes'koyi derzhavnoyi akademiyi budivnytstva ta arkhitektury. 2008. 29(1), 371-380.

Smith R.: Chemical process design. (New York: McGraw-Hill, 1999).

Smith R. at al.: Basics of the integration of thermal processes. (Kharkov: NTU "KhPI", 2000). [In Russian].

Soo S.S.T. Toh E.L., Yap K.K.K., . Ng D.K.S., Foo D.C.Y. Synthesis of distributed wastewater treatment networks for one- and two-contaminant systems. Chem. Engng. R\&D. 2013. 91(1), 106119. doi: https://doi.org/10.1016/j.cherd.2012.06.015

Statyukha G. A., Kvitka O. O., Shakhnovsky A. M. Modeling of industrial water consumption schemes based on the structural parameters method. Ekotekhnologii i resursozberezhennya (Ecotechnologies and resource saving). 2003. 5, 57-62. [In Ukrainian]. 
Tainsh R.A., Rudman A. R. Practical techniques and methods to develop an efficient water management strategy. Linnhoff March International, Paper presented at: IQPC conference 'Water Recycling and Effluent Re-Use'. In: KBC Advanced Technologies PLC. - 1999. URL: http://devkbcat.contentactive.com/default/documents/technical\%20papers/IQPC_Water_Paper.pdf

Takama N., Kiriyama T., Shiroko K., Umeda T. Optimal water allocation in a petroleum refinery. Computers \& Chemical Engineering. 1980. 4(4), 251-258. doi: https://doi.org/10.1016/00981354(80)85005-8

Wang Y.P., Smith R. Wastewater minimization. Chem. Eng. Sci. 1994a. 49(7), 981-1006. doi: https://doi.org/10.1016/0009-2509(94)80006-5

Wang Y.P., Smith R. Design of distributed effluent treatment systems. Chem. Eng. Sci. 1994b. 49(18), 3127-3145. doi: https://doi.org/10.1016/0009-2509(94)E0126-B

Wang Y.P., Smith R. Wastewater minimization with flowrate constraints. Chemical Engineering Research and Design. 1995. 73 (Part A), 889-904. ResearchGate: https://www.researchgate.net/publication/279602119_Wastewater_minimization_with_flowrate_co nstraints

Young D. M., Cabezas H. Designing sustainable processes with simulation: the waste reduction (WAR) algorithm. Comp. \& Chem. Engng. 1999. 23(10), 1477-1491. doi: https://doi.org/10.1016/S0098-1354(99)00306-3

Zhelev T. K., Bhaw N. Combined water-oxigen pinch analysis for better wastewater treatment management. Waste management. 2000. 20 (8), 665-670. doi: https://doi.org/10.1016/S0956$\underline{053 X(00) 00050-7}$ 